\title{
DNA Relatedness among Strains of the Streptomyces lavendulae Phenotypic Cluster Group
}

\author{
D. P. LABEDA \\ Microbial Properties Research, National Center for Agricultural Utilization Research, Agricultural \\ Research Service, U.S. Department of Agriculture, Peoria, Illinois 61604
}

\begin{abstract}
DNA relatedness was evaluated among the type strains of Streptomyces lavendulae and the 11 species which were designated as subjective synonyms in volume 4 of Bergey's Manual of Systematic Bacteriology. Three $S$. lavendulae subspecies, five putative strains of $S$. lavendulae, and the type strain of " $S$. majorciensis" were also included in the present study. The 21 strains studied segregated into 14 clusters (average linkage) when grouped at $>70 \%$ DNA relatedness, including 10 single-member clusters. $S$. lavendulae, $S$. lavendulae subsp. avirens, $S$. lavendulae subsp. grasserius, and $S$. columbiensis were found to be synonymous at $>79 \%$ DNA relatedness. The other clusters, on the basis of their relatively low DNA relatedness to $S$. lavendulae, appear to be valid species rather than subjective synonyms of $S$. lavendulae.
\end{abstract}

The Streptomyces lavendulae phenotypic cluster of Williams et al. (14) was selected for study as a continuation of previous investigations into DNA relatedness in the genus Streptomyces. The strains in this cluster group are morphologically similar, having rust-colored to red, smooth, cylindrical to ovoid spores borne on sphorophores that form fairly large, open spirals. In addition, many of the strains evaluated in the present study produce similar secondary metabolites of the streptothricin class. The studies of Williams et al. (14), as reflected in volume 4 of Bergey's Manual of Systematic Bacteriology (13), indicated that all of the species in the present study belong to the same phenotypic cluster and thus should be considered subjective synonyms of $S$. lavendulae. The recent paper of Kämpfer et al. (1), again based on phenotypic numerical taxonomic results, also concluded that all of these strains belonged to a single species because they clustered together, except for $S$. xanthophaeus, which formed a single member cluster. Previous studies of the $S$. cyaneus (3) and $S$. violaceusniger (4) clusters in our laboratory have shown that the phenotypic cluster groups formed by numerical taxonomic studies do not necessarily represent single species based on genomic similarity. Witt and Stackebrandt (15), in their paper suggesting the reunification of the genera Streptoverticillium and Streptomyces on the basis of 16S rRNA sequence data, noted that, on the phylogenetic tree generated by their data, $S$. lavendulae is separated from the major portion of the genus Streptomyces by the genus Streptoverticillium. All of the observations mentioned above made the determination of the degree of genomic relatedness among members of the phenotypic $S$. lavendulae cluster of great interest.

\section{MATERIALS AND METHODS}

Strains, cultivation, and maintenance. All strains studied in the present investigation are held in the ARS Culture Collection, National Center for Agricultural Utilization Research, Peoria, Ill. A summary of the strains included in the study and the secondary metabolites produced by them, if known, is given in Table 1. Primary storage of strains was as refrigerated ampoules of freeze-dried suspensions of spores and vegetative mycelium in sterile beef serum. Working stock cultures were maintained on slants of yeast extractmalt extract agar (10) or inorganic salts-starch agar (10) and stored at $4^{\circ} \mathrm{C}$ until needed. Biomass for extraction of DNA was grown as shaken cultures in Fernbach flasks containing tryptone glucose-liver extract-yeast extract broth (7).

Purification of DNA and determination of relatedness. DNA was extracted by the method of Marmur (6) after cell disruption by passage through a French pressure cell (SLM Instruments, Inc., Urbana, Ill.) at $10,000 \mathrm{lb} / \mathrm{in}^{2}$. The DNA was further purified by hydroxylapatite chromatography or cesium chloride density gradient centrifugation (5). Individual strains generally yielded 5 to $10 \mathrm{mg}$ of DNA from 85 to $100 \mathrm{~g}$ of biomass in initial preparations. The percentage of DNA relatedness between strains was calculated from $C_{0} t_{0.5}$ determinations in $5 \times \mathrm{SSC}(1 \times \mathrm{SSC}$ is $0.15 \mathrm{M}$ sodium chloride and $0.015 \mathrm{M}$ sodium citrate) supplemented with $20 \%$ dimethyl sulfoxide at $65^{\circ} \mathrm{C}\left(T_{m}-23^{\circ} \mathrm{C}\right)$ by the methods of Seidler and coworkers $(8,9)$ as described by Kurtzman et al. (2). The standard error for this method was determined to be $\pm 5 \%$.

Data analysis. Statistical calculations of the clustering of DNA relatedness data were performed with SAS for Personal Computers, release 6.04 (SAS Institute Inc., Cary, N.C.), on a DTK Datatek FEAT 3300 80486-33 microcomputer. The data were clustered by the average linkage algorithm (11) by the SAS/STAT CLUSTER procedure, and the dendrogram was generated with SAS/GRAPH with the SAS macro GRAFTREE written and kindly provided by Dan Jacobs, University of Maryland.

\section{RESULTS}

The data for DNA relatedness among strains in this study are shown in tabular form in Table 2. There are four major cluster groups observed at $>70 \%$ DNA relatedness, which has been defined as species-level homology (12). The major cluster group is the $S$. lavendulae cluster, consisting of two strains of $S$. lavendulae, NRRL B-1230 (the type strain) and NRRL B-5617; $S$. columbiensis NRRL B-1990; and S. lavendulae subsp. avirens and $S$. lavendulae subsp. grasserius (NRRL B-16576 and NRRL B-3072, respectively). The other clusters observed are the $S$. toxytricini cluster, consisting of strain NRRL B-5426 and $S$. lavendulae subsp. brasilicus NRRL B-2937; the $S$. racemochromogenes cluster, consisting of NRRL B-5430 and $S$. lavendulae NRRL B-3080; and the $S$. polychromogenes cluster, consisting of NRRL B-12233 and $S$. lavendulae NRRL B-2343. These data can be seen graphically in the dendrogram in Fig. 1, which was 
TABLE 1. Streptomyces strains used in this study

\begin{tabular}{lll}
\hline \multicolumn{1}{c}{ Species or subspecies } & NRRL no. & \multicolumn{1}{c}{ Product(s) } \\
\hline S. columbiensis & B-1990 & Cyanocobalamine \\
S. flavotricini & $\mathrm{B}-5419^{\mathrm{T}}$ & \\
S. goshikiensis & $\mathrm{B}-5428^{\mathrm{T}}$ & Bandamycin \\
S. katrae & $\mathrm{B}-3093^{\mathrm{T}}$ & \\
S. lavendulae & $\mathrm{B}-1230^{\mathrm{T}}$ & Streptothricins \\
S. lavendulae & $\mathrm{B}-2343$ & Cycloserine \\
S. lavendulae & $\mathrm{B}-2402$ & Mycobacidin \\
S. lavendulae & $\mathrm{B}-3080$ & \\
S. lavendulae subsp. & $\mathrm{B}-3904$ & \\
inositophilus & & \\
S. lavendulae & $\mathrm{B}-5617$ & Streptothricins \\
S. lavendulae subsp. avirens & $\mathrm{B}-16576$ & Streptothricins \\
S. lavendulae subsp. brasilicus & $\mathrm{B}-2937$ & \\
S. lavendulae subsp. grasserius & $\mathrm{B}-3072$ & Grasseriomycin \\
S. lavendulocolor & $\mathrm{B}-3367^{\mathrm{T}}$ & \\
"S. majorciensis" & 15167 & C08078 $\alpha$ \\
S. polychromogenes & $\mathrm{B}-12233^{\mathrm{T}}$ & O-Carbamyl-D-serine \\
S. racemochromogenes & $\mathrm{B}-5430^{\mathrm{T}}$ & Racemomycin \\
S. subrutilus & $\mathrm{B}-12377^{\mathrm{T}}$ & Hydroxystreptomycin \\
S. toxytricini & $\mathrm{B}-5426^{\mathrm{T}}$ & \\
S. virginiae & $\mathrm{B}-1446^{\mathrm{T}}$ & Actithiazic acid \\
S. xanthophaeus & $\mathrm{B}-5414^{\mathrm{T}}$ & Geomycin \\
\hline
\end{tabular}

generated after clustering of the data by the average linkage algorithm (11).

\section{DISCUSSION}

The results observed in the present study were analogous to those reported by our laboratory in previous investigations of DNA relatedness among strains in the $S$. cyaneus (3) and $S$. violaceusniger (4) phenotypic cluster groups defined by numerical taxonomy. For all three species evaluated thus far, the majority of the species names designated as subjec- tive synonyms of other species as a result of numerical taxonomic analysis were found to be distinct species because they exhibited DNA relatedness values of less than $70 \%$ with the other strains in their respective species clusters. These results would thus not conform to the suggested guideline that strains of the same species must exhibit $>70 \%$ genomic homology (12). Table 2 clearly shows that the majority of the strains in the $S$. lavendulae phenotypic cluster cannot be considered as members of this species. Witt and Stackebrandt (15) reported data for DNA relatedness between the type strain and strains comprising $S$. lavendulae and its subjective synonyms (except $S$. flavotricini) in volume 4 of Bergey's Manual of Systematic Bacteriology (13) and found that the type strain of $S$. columbiensis was the only strain studied that is highly related to the type strain of S. lavendulae. The ARS Culture Collection contained many strains of $S$. lavendulae, so the genetic diversity among a representative sampling of these strains could be evaluated. The present study confirmed the finding of Witt and Stackebrandt, but also showed that $S$. lavendulae NRRL B-5617 and S. lavendulae subsp. avirens (NRRL B-16576) and $S$. lavendulae subsp. grasserius (NRRL B-3072), as well as the type strain of $S$. columbiensis (NRRL B-1990), were valid members of the species $S$. lavendulae. This is not too surprising, since these strains are morphologically very similar and all produce streptothricin, except $S$. columbiensis, which produces cyanocobalamine. The strains of the $S$. lavendulae DNA relatedness cluster group are seen as distant from the other strains designated as subjective synonyms for $S$. lavendulae when the data are observed as a simple dendrogram after average linkage clustering (Fig. 1). Clearly, these strains compose the authentic species $S$. lavendulae. It is interesting that $S$. racemochromogenes NRRL B-5430 and S. xanthophaeus NRRL B-5414, both of which produce antibiotics of the streptothricin class and are morphologically very similar to

TABLE 2. DNA relatedness among strains of the $S$. lavendulae cluster

\begin{tabular}{|c|c|c|c|c|c|c|c|c|c|c|c|c|c|c|c|c|c|c|c|c|c|}
\hline \multirow[b]{2}{*}{ Strain name } & \multirow[b]{2}{*}{ NRRL no. } & \multicolumn{20}{|c|}{$\%$ DNA relatedness to ${ }^{a}:$} \\
\hline & & $\begin{array}{l}\text { త్లి } \\
\text { ติ }\end{array}$ & $\begin{array}{l}\vec{b} \\
\tilde{n} \\
\infty\end{array}$ & $\frac{\stackrel{g}{\sigma}}{\dot{n}}$ & $\begin{array}{l}\frac{0}{6} \\
\frac{1}{6} \\
\frac{1}{6}\end{array}$ & $\begin{array}{l}\stackrel{N}{S} \\
\text { ஸे }\end{array}$ & 芹 & ஸิ & 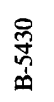 & 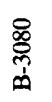 & $\frac{\text { 导 }}{\text { ñ }}$ & $\begin{array}{l}\stackrel{9}{\vec{H}} \\
\ddot{n}\end{array}$ & 売 & $\frac{\hat{\Xi}}{\tilde{\theta}}$ & 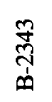 & $\begin{array}{l}\text { s్ } \\
\text { n' }\end{array}$ & $\underset{\overparen{3}}{\stackrel{5}{a}}$ & $\begin{array}{l}\text { ¿্. } \\
\text { ஸ் }\end{array}$ & 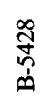 & 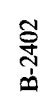 & $\begin{array}{l}5 \\
\text { n్ }\end{array}$ \\
\hline S. lavendulae & B-5617 & 100 & & & & & & & & & & & & & & & & & & & \\
\hline S. columbiensis & B-1990 & 83 & 94 & & & & & & & & & & & & & & & & & & \\
\hline S. lavendulae subsp. avirens & B-16576 & 88 & 90 & 100 & & & & & & & & & & & & & & & & & \\
\hline S. lavendulae subsp. grasserius & B-3072 & 84 & 81 & 100 & 79 & & & & & & & & & & & & & & & & \\
\hline S. toxytricini & B-5426 & 47 & 26 & 34 & 36 & 39 & & & & & & & & & & & & & & & \\
\hline S. lavendulae subsp. brasilicus & B-2937 & 39 & 17 & 47 & 20 & 23 & 92 & & & & & & & & & & & & & & \\
\hline S. racemochromogenes & B-5430 & 39 & 38 & 40 & 39 & 38 & 63 & 30 & & & & & & & & & & & & & \\
\hline S. lavendulae & B-3080 & 45 & 25 & 56 & 57 & 45 & 44 & 46 & 78 & & & & & & & & & & & & \\
\hline S. virginiae & B-1446 & 43 & 34 & 42 & 37 & 39 & 35 & 31 & 51 & 52 & & & & & & & & & & & \\
\hline S. flavotricini & B-5419 & 13 & 36 & 40 & 27 & 26 & 40 & 24 & 45 & 34 & 60 & & & & & & & & & & \\
\hline S. xanthophaeus & B-5414 & 36 & 30 & 53 & 34 & 45 & 25 & 16 & 37 & 42 & 40 & 48 & & & & & & & & & \\
\hline S. polychromogenes & B-12233 & 33 & 29 & 44 & 35 & 40 & 27 & 38 & 44 & 35 & 31 & 48 & 33 & & & & & & & & \\
\hline S. lavendulae & B-2343 & 30 & 35 & 28 & 24 & 36 & 34 & 23 & 39 & 27 & 49 & 29 & 27 & 71 & & & & & & & \\
\hline S. katrae & B-3093 & 35 & 33 & 47 & 37 & 42 & 28 & 31 & 47 & 63 & 35 & 33 & 30 & 59 & 65 & & & & & & \\
\hline S. subrutilus & B-12377 & 27 & 23 & 45 & 25 & 34 & 27 & 43 & 36 & 41 & 31 & 30 & 43 & 25 & 36 & 34 & & & & & \\
\hline S. lavendulae subsp. inositophilus & B-3904 & 32 & 13 & 20 & 23 & 31 & 37 & 12 & 36 & 19 & 36 & 28 & 40 & 50 & 22 & 37 & 37 & & & & \\
\hline S. goshikiensis & B-5428 & 12 & 22 & 37 & 30 & 41 & 31 & 27 & 28 & 39 & 36 & 27 & 29 & 38 & 29 & 38 & 31 & 33 & & & \\
\hline S. lavendulae & B-2402 & 26 & 21 & 35 & 4 & 7 & 24 & 10 & 0 & 5 & 43 & 3 & 30 & 27 & 13 & 2 & 6 & 10 & 14 & & \\
\hline "S. majorciensis" & 15167 & 12 & 35 & 13 & 37 & 35 & 37 & 33 & 32 & 31 & 41 & 34 & 21 & 24 & 18 & 42 & 29 & 13 & 23 & 35 & \\
\hline S. lavendulocolor & B-3367 & 20 & 8 & 27 & 13 & 13 & 17 & 9 & 13 & 20 & 12 & 32 & 26 & 9 & 0 & 11 & 13 & 21 & 31 & 30 & 6 \\
\hline
\end{tabular}

a Standard error is $\pm 5 \%$ DNA relatedness.

b $S$. lavendulae NRRL B-1230. 


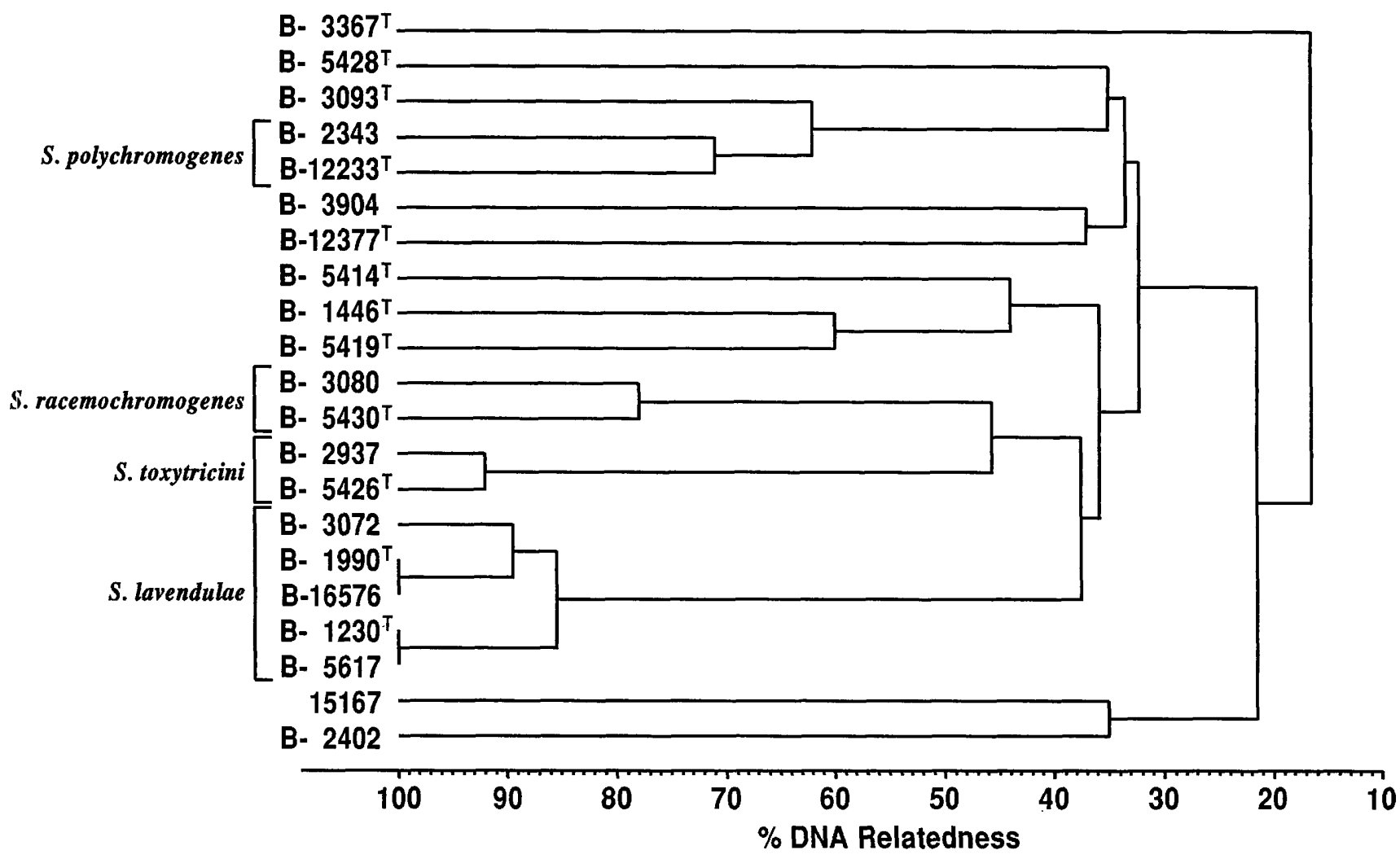

FIG. 1. Dendrogram of DNA relatedness among strains of the $S$. lavendulae phenotypic cluster group after clustering by the average linkage algorithm.

S. lavendulae, generally exhibit very low DNA relatedness to the members of the $S$. lavendulae DNA relatedness group and to each other. $S$. racemochromogenes NRRL B-5430, however, does exhibit species-level DNA relatedness $(78 \%)$ to one of the strains deposited in the ARS Culture Collection as $S$. lavendulae, NRRL B-3080. These strains would appropriately constitute the genetically defined species $S$. racemochromogenes, rather than subjective synonyms of $S$. lavendulae. Similarly, $S$. lavendulae subsp. brasilicus NRRL B-2937 exhibits species-level DNA relatedness (92\%) to $S$. toxytricini NRRL B-5426, while $S$. lavendulae NRRL B-2343 exhibits significant DNA relatedness $(71 \%)$ to $S$. polychromogenes NRRL B-12233. Interestingly, the latter two strains produce serine-derived antibiotics, cycloserine and $O$-carbamyl-D-serine, respectively.

The other strains included in the present study appear to represent individual monotypic species on the basis of DNA relatedness. S. columbiensis NRRL B-1990 exhibits reproducible but unexpected genomic relatedness of 56 and $53 \%$ with S. lavendulae NRRL B-3080 and S. xanthophaeus NRRL B-5414, respectively, but the taxonomic relationship indicated by this level of homology is unclear at this time. Also included among the monotypic strains is the invalid taxon " $S$. majorciensis," which was isolated and described by me as part of a natural products discovery program at Lederle Laboratories. This strain produces the growth promotant $C 08078 \alpha$ and does appear to be a valid new species, from the extent of DNA relatedness with described taxa. An evaluation of the physiological properties of these strains, perhaps in conjunction with the physiological profiles generated by Williams et al. (14) and Kämpfer et al. (1), will be necessary before these taxa can be redescribed in terms of their DNA relatedness and morphological and physiological properties.

\section{ACKNOWLEDGMENT}

The able technical assistance of E. N. Hoekstra in the isolation and purification of DNA and performance of many of the DNA hybridizations required for this study is gratefully acknowledged.

\section{REFERENCES}

1. Kämpfer, P., R. M. Kroppenstedt, and W. Dott. 1991. A numerical classification of the genera Streptomyces and Streptoverticillium using miniaturized physiological tests. J. Gen. Microbiol. 137:1831-1891.

2. Kurtzman, C. P., M. J. Smiley, C. J. Johnson, L. J. Wickerham, and G. B. Fuson. 1980. Two new and closely related heterothallic species, Pichia amylophila and Pichia mississippiensis: characterization by hybridization and deoxyribonucleic acid reassociation. Int. J. Syst. Bacteriol. 30:208-216.

3. Labeda, D. P., and A. J. Lyons. 1991. Deoxyribonucleic acid relatedness among species of the "Streptomyces cyaneus" cluster. Syst. Appl. Microbiol. 14:158-164.

4. Labeda, D. P., and A. J. Lyons. 1991. The Streptomyces violaceusniger cluster is heterogeneous in DNA relatedness among strains: emendation of the descriptions of $S$. violaceusniger and Streptomyces hygroscopicus. Int. J. Syst. Bacteriol. 41:398-401.

5. Maniatis, T., E. F. Fritsch, and J. Sambrook. 1982. Molecular cloning: a laboratory manual. Cold Spring Harbor Laboratory, Cold Spring Harbor, N.Y.

6. Marmur, J. 1961. A procedure for the isolation of deoxyribonucleic acid from microorganisms. J. Mol. Biol. 3:208-218.

7. Pridham, T. G., and A. J. Lyons. 1980. Methodologies for 
Actinomycetales with special reference to streptomycetes and streptoverticillia, p. 153-224. In A. Dietz and D. W. Thayer (ed.), Actinomycete taxonomy. Special publication no. 6. Society for Industrial Microbiology, Arlington, $\mathrm{Va}$

8. Seidler, R. J., M. D. Knittel, and C. Brown. 1975. Potential pathogens in the environment: cultural reactions and nucleic acid studies on Klebsiella pneumoniae from chemical and environmental sources. Appl. Microbiol. 29:819-825.

9. Seidler, R. J., and M. Mandel. 1971. Quantitative aspects of deoxyribonucleic acid renaturation: base composition, state of chromosome replication, and polynucleotide homologies. J. Bacteriol. 106:608-614.

10. Shirling, E. B., and D. Gottlieb. 1966. Methods for characterization of Streptomyces species. Int. J. Syst. Bacteriol. 16:313340.

11. Sneath, P. H. A., and R. R. Sokal. 1973. Numerical taxonomy. W. H. Freeman and Company, San Francisco.

12. Wayne, L. G., D. J. Brenner, R. R. Colwell, P. A. D. Grimont,
O. Kandler, M. I. Krichevsky, L. H. Moore, W. E. C. Moore, R. G. E. Murray, E. Stackebrandt, M. P. Starr, and H. G. Trüper. 1987. Report of the ad hoc committee on reconciliation of approaches to bacterial systematics. Int. J. Syst. Bacteriol. 37:463-464.

13. Williams, S. T., M. Goodfellow, and G. Alderson. 1989. Genus Streptomyces Waksman and Henrici 1943, 339 AL, p. 2452-2492. In S. T. Williams, M. E. Sharpe, and J. G. Holt, (ed.), Bergey's manual of systematic bacteriology, vol. 4. Williams and Wilkins, Baltimore.

14. Williams, S. T., M. Goodfellow, G. Alderson, E. M. H. Wellington, P. H. A. Sneath, and M. J. Sakin. 1983. Numerical classification of Streptomyces and related genera. J. Gen. Microbiol. 129:1743-1813.

15. Witt, D., and E. Stackebrandt. 1990. Unification of the genera Streptoverticillium and Streptomyces, and emendation of Streptomyces Waksman and Henrici 1943, 339 AL. Syst. Appl. Microbiol. 13:361-371. 